\title{
Superiority of living animal models in microsurgical training: beyond technical expertise
}

\author{
Konstantinos Gasteratos ${ }^{1} \cdot$ Joseph Robert Paladino ${ }^{2} \cdot$ Yelena Akelina $^{3} \cdot$ Horacio F. Mayer $^{4}$ (D
}

Received: 9 January 2021 / Accepted: 2 February 2021 / Published online: 11 February 2021

(C) The Author(s), under exclusive licence to Springer-Verlag GmbH, DE part of Springer Nature 2021

\begin{abstract}
Background Many studies are investigating the role of living and nonliving models to train microsurgeons. There is controversy around which modalities account for the best microsurgical training. In this study, we aim to provide a systematic literature review of the practical modalities in microsurgery training and compare the living and nonliving models, emphasizing the superiority of the former. We introduce the concept of non-technical skill acquisition in microsurgical training with the use of living laboratory animals in the context of a novel proposed curriculum.

Methods A literature search was conducted on PubMed/Medline and Scopus within the past 11 years based on a combination of the following keywords: "microsurgery," "training," "skills," and "models." The online screening process was performed by two independent reviewers with the Covidence tool. A total of 101 papers was identified as relevant to our study. The protocol was reported in line with the Preferred Reporting Items for Systematic Reviews and Meta-Analyses (PRISMA) statement.

Results Living models offer the chance to develop both technical and non-technical competencies (i.e., leadership, situation awareness, decision-making, communication, and teamwork). Prior experience with ex vivo tissues helps residents consolidate basic skills prior to performing more advanced techniques in the living tissues. Trainees reported a higher satisfaction rate with the living models.

Conclusions The combination of living and nonliving training microsurgical models leads to superior results; however, the gold standard remains the living model. The validity of the hypothesis that living models enhance non-technical skills remains to be confirmed.

Level of evidence: Not ratable.
\end{abstract}

Keywords Microsurgery $\cdot$ Training models $\cdot$ Nonliving models $\cdot$ Technical skills $\cdot$ Non-technical skills

\section{Introduction}

Many studies are investigating the role of living and nonliving models to train microsurgeons. In the current literature, there is controversy around which modalities account for the best

Horacio F. Mayer

horacio.mayer@hospitalitaliano.org

1 Department of Plastic and Reconstructive Surgery, Papageorgiou General Hospital, Thessaloniki, Greece

2 Sidney Kimmel Medical College, Thomas Jefferson University, Philadelphia, PA, USA

3 Department of Orthopedic Surgery, Columbia University Irving Medical Center, New York, NY, USA

4 Plastic Surgery Department, Hospital Italiano de Buenos Aires, University of Buenos Aires School of Medicine, Hospital Italiano de Buenos Aires University Institute, Buenos Aires, Argentina microsurgical training. Living models include live animals used in the laboratory for research and/or experiments. Nonliving models are subdivided in the following categories: (a) non-vital, such as chicken wing/thigh [1] or aorta [2], porcine trotters, and human cadavers [3]; (b) prosthetic; and (c) virtual reality [4]. One major difference between these two broad categories is the lack of blood circulation in the ceased specimens. Thus, the trainee microsurgeon is unable to practice intraoperative hemostasis and postsurgical assessment of anastomotic patency (i.e., the survival of the reconstructed flap).

International consensuses on minimum standards for microsurgical courses $[5,6]$, minimum microsurgery case requirements [7], and several validated training models with objective structured assessment of technical skills (OSATS) have been devised to evaluate the trainees' performance in microsurgery [8-11]. The development of assessment tools for robot-assisted microsurgery (RAMS) skills is still in progress [12-15]. All of these innovative grading tools are comprehensive and reliable for assessing the students' progress 
throughout a microsurgical course [16, 17]. However, they focus solely on the technical aspects [18], such as manual dexterity, hand-eye coordination, meticulous suture placement [19, 20], speed, operative flow, motion [21], and patency of the anastomosis based on task-specific checklists [22-26].

On the other hand, non-technical skills (NTS) are equally important. Non-technical skills include five broad categories: leadership, situation awareness, decision-making, communication, and teamwork [27, 28]. Recent research has shown non-technical skills are important to successful outcomes; up to $43 \%$ of errors made in surgery can be attributed to poor communication in the operating room [29]. In the operating room, NTS rise to the forefront when completing a procedure. Without prior exposure to NTS acquisition, surgeons are left to learn these skill sets while in the operating room. The need for proper evaluation of these skills when examining and treating patients is critical. However, empirical evidence suggests that there is a gap in current microsurgical training by means of not incorporating NTS into the curriculum, and by the use of solely nonliving models by some programs.

In this study, we aim to provide a systematic literature review of the practical modalities in microsurgery training and compare the living and nonliving models, emphasizing the superiority of the living models. Also, we introduce the concept of non-technical skill acquisition in microsurgical training with the use of living laboratory animals in the context of a novel proposed curriculum.

\section{Materials and methods}

A systematic literature review was conducted in PubMed/ Medline and Scopus. The keywords used to identify relevant literature in PubMed were the following: "microsurgery," "training," "skills," and "models." The filters applied were English language and articles within the past 11 years. Two independent reviewers (K.G., J.R.P.) performed the search and screening process, based on title and abstract with the Covidence tool. Irrelevant articles were screened against the following inclusion and exclusion criteria. Conflicts in the selection process were resolved by discussion between these two authors.

Inclusion criteria:

- microsurgical training models

- both living and nonliving models

- experimental studies

- English language

- studies available electronically

Exclusion criteria:

- non-microsurgical training models

- human studies
- Letters to the Editor/correspondence

- articles without an abstract or full text

- non-English articles

We focused on articles on experimental living and nonliving microsurgical training models and their effect in nontechnical skill acquisition. We intend to perform a metaanalysis depending on the homogeneity or heterogeneity of the results from our study.

\section{Results}

PubMed/Medline and Scopus searches between 2010 and 2020 yielded 121 and 186 papers, respectively. Upon application of filters (within the past 11 years, English language) and screening for eligibility, relevant PubMed/Medline and Scopus articles accounted for 48 and 53, respectively. A total of 101 articles was included in the study. The Preferred Reporting Items for Systematic Reviews and Meta-Analyses (PRISMA) algorithm is shown in Fig. 1. The study designs and methodologies were highly variable among the articles. The data retrieved were heterogeneous and could not be combined numerically. Therefore, a review was performed without a meta-analysis. For the included studies, the following information was extracted: (a) authors (year of publication), (b) demographics, (c) training modality, (d) type of skills assessed, and (e) conclusion. A summary of the major studies is described in Table 1.

\section{Advantages of living training models}

Throughout the history of microsurgery evolution, there are many outstanding examples of using live animals in experimental microsurgery. Firstly, the Nobel Prize winner Alexis Carrel (1902) performed transplantation of several organs in animals and invented the triangulation technique in vascular repair. In 1903, Hopfner was the first to report the successful mid-thigh limb replantation in a dog. In 1964, Buncke and Schulz performed the first total ear replantation in a rabbit [30]. Today, we learn from these experiments and revolutionize these techniques in human patients.

Live animal models have long been used as a means to train microsurgeons since they are considered the gold standard with many pros $[31,32]$. Rats, in particular, are larger in size than mice; therefore, there is an abundance of tissues to work with and perform multiple exercises all in one specimen. That leads to a reduction in the number of live animals required, which translates to cost-effectiveness. In addition, the physiology of the rat is closer to that of the human. Established protocols in experimental surgery exist for usage of laboratory rat models in the study of virtually all anatomical systems $[33,34]$. 
Fig. 1 The screening process as per the PRISMA algorithm
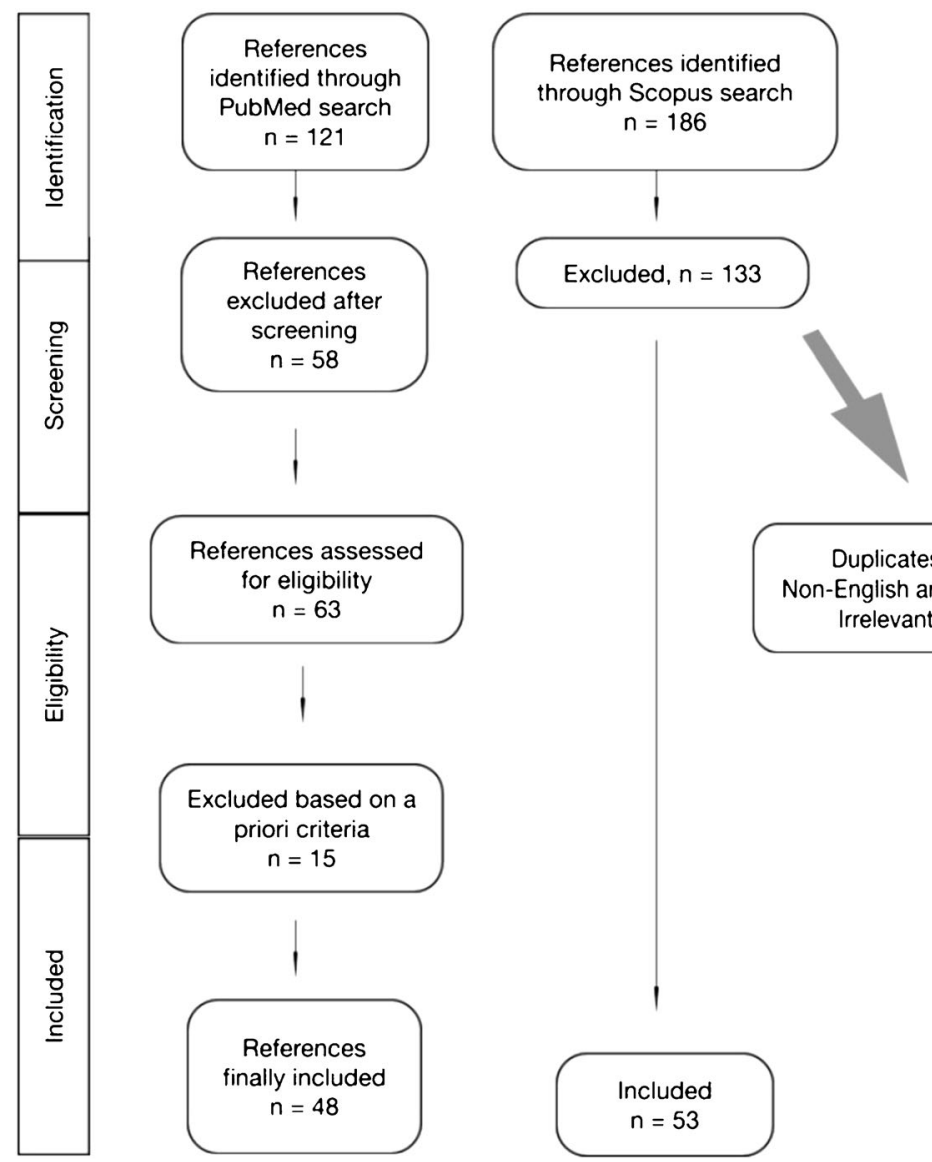

Duplicates, $n=52$

Non-English articles, $n=14$ Irrelevant, $n=67$
Rat vessels are a very close prototype of humane vessels that gives trainees an extra edge of competence. The trainees learn immaculate dissecting skills using hemostasis and ligating branches from main vessels. Advanced training exercises can be performed by trainees in rabbits, such as interposition vein graft [35], bypass graft, free tissue transfer (e.g., groin flap), and auricular transplantation. Apart from building technical skills faster and more efficiently under the guidance of an expert instructor [36], the presence of an experienced teacher during the execution of these exercises is fundamental in acquiring communication, teamwork, and decision-making skills.

Working with live rats simulates the operating theater experience because the rat is anesthetized. An intraperitoneal infusion of ketamine is administered before and throughout the exercises by the trainee to minimize the pain suffered by the animal. The institutions which organize living model courses are well established and have legal approval to run as per the official research ethical regulations in each country [37]. Also, a simulation environment which resembles a real operating room (OR) contributes to the engagement of the trainee. For example, operating in a theater suite scrubbed and mentally prepared to perform a challenging exercise puts the surgeon in a position of responsibility and raises pressure. This situation is difficult to generate with a do-it-yourself (DIY) device at home, even though such practice helps to maintain basic technical microsurgical skills. Some training centers have linked the role of positive psychology and spiritual alertness with successful outcomes [37].

Preliminary studies show the detrimental effect of external stressors and cognitive distraction to the accuracy of microsurgical performance [38]. Simulation assists learners to become more dexterous and competent in controlling their level of anxiety or stress [39], thus decreasing hand tremor and improving their overall performance in simulated settings [40]. As a result, trainees begin being capable of handling challenging situations in the real clinical environment.

The living model offers the chance to develop nontechnical competencies, including decision-making capacities and stress management while operating. Several examples of non-technical skills include communication with instructors and colleagues, observational learning, time management, awareness of intraoperative distractions, reflective practice, and consolidation of ethical practice (i.e., administering anesthesia and assessing for pain) [41, 42].

Due to the variability of the experimental living models, the residents learn the importance of flexibility, judgment, and readiness to make a decision. In so doing, residents develop a surgical reconstructive plan given the unique task at hand. Technical and non-technical skills attained from live rats are transferable to the human operating room. 
Table 1 List of major systematic reviews on various training modalities in microsurgery

\begin{tabular}{|c|c|c|c|c|}
\hline Author (year) & Type of study & Training modality & Skills assessed & Conclusion \\
\hline $\begin{array}{l}\text { Abi-Rafeh et al. } \\
\text { (2019) [80] }\end{array}$ & Systematic review & $\begin{array}{l}\text { Nonbiological (prosthetic } \\
\text { models, VR) }\end{array}$ & Technical & $\begin{array}{l}\text { Reduction in live experimental animal } \\
\text { for microsurgery training }\end{array}$ \\
\hline $\begin{array}{l}\text { Beris et al. } \\
\quad(2020)[31]\end{array}$ & $\begin{array}{l}\text { Descriptive study of } \\
\text { novel proposed } \\
\text { curriculum }\end{array}$ & $\begin{array}{l}\text { Live lectures, e-learning } \\
\text { modules, nonliving and living } \\
\text { models, VR }\end{array}$ & Technical & $\begin{array}{l}\text { Combination of teaching methods } \\
\text { yields high performance }\end{array}$ \\
\hline $\begin{array}{l}\text { Brown and Rapaport } \\
\text { (2016) [32] }\end{array}$ & Systematic review & LF and HF models & Technical & $\begin{array}{l}\text { Advocates LF models as excellent } \\
\text { alternatives to HF models }\end{array}$ \\
\hline $\begin{array}{l}\text { Dumestre et al. (2014) } \\
\text { [8] }\end{array}$ & Systematic review & $\begin{array}{l}\text { LF and HF models, basic and } \\
\text { advanced }\end{array}$ & Technical & $\begin{array}{l}\text { Each model offers unique training } \\
\text { features }\end{array}$ \\
\hline $\begin{array}{l}\text { Dumestre et al. } \\
\text { (2015) [25] }\end{array}$ & Systematic review & Mixture of methods & $\begin{array}{l}\text { Technical (e.g., motion } \\
\text { analysis, dexterity) }\end{array}$ & $\begin{array}{l}\text { Examines types of objective } \\
\text { assessment tools of microsurgical } \\
\text { skills }\end{array}$ \\
\hline $\begin{array}{l}\text { Ghanem et al. } \\
\text { (2013) [33] }\end{array}$ & Systematic review & Mixture of methods & Technical & Quality analysis of other studies \\
\hline $\begin{array}{l}\text { Javid et al. } \\
\quad \text { (2019) [34] }\end{array}$ & Systematic review & $\begin{array}{l}\text { Mixture of methods (bench, } \\
\text { cadaveric animal, live animal, } \\
\text { cadaveric human, VR) }\end{array}$ & Technical & $\begin{array}{l}\text { Lack of good LoE microsurgical } \\
\text { simulators }\end{array}$ \\
\hline $\begin{array}{l}\text { Margulies et al. } \\
\quad(2020)[35]\end{array}$ & Systematic review & $\begin{array}{l}\text { Interactive and passive digital } \\
\text { resources (e.g., YouTube } \\
\text { videos, e-learning, social } \\
\text { media platforms, smartphone } \\
\text { applications, VR) }\end{array}$ & Technical & $\begin{array}{l}\text { Adjuncts to traditional training } \\
\text { modalities }\end{array}$ \\
\hline $\begin{array}{l}\text { Pafitanis et al. } \\
\text { (2018) [36] }\end{array}$ & Systematic review & $\begin{array}{l}\text { Living and nonliving SM } \\
\text { models }\end{array}$ & Technical & Proposed SM curriculum \\
\hline $\begin{array}{l}\text { Chouari et al. } \\
\text { (2018) [3] }\end{array}$ & Experimental study & $\begin{array}{l}\text { Artificially perfused fresh frozen } \\
\text { cadavers }\end{array}$ & Technical & $\begin{array}{l}\text { Significant improvement in training } \\
\text { potential }\end{array}$ \\
\hline $\begin{array}{l}\text { Almeland et al. } \\
\text { (2020) [9] }\end{array}$ & RCT & $\begin{array}{l}\text { Silicone tube (microsurgery) } \\
\text { Latex model (macrosurgery) }\end{array}$ & $\begin{array}{l}\text { Technical (microscopic } \\
\text { and macroscopic) }\end{array}$ & $\begin{array}{l}\text { Poorer macrosurgical skills in medical } \\
\text { students exposed only to } \\
\text { microsurgical training vs both }\end{array}$ \\
\hline $\begin{array}{l}\text { van Mulken et al. } \\
\text { (2018) [14] }\end{array}$ & Preclinical study & Microsure robotic system & Technical & $\begin{array}{l}\text { Steeper learning curve and poorer } \\
\text { performance with robot vs } \\
\text { conventional method }\end{array}$ \\
\hline $\begin{array}{l}\text { Paladino et al. } \\
\text { (2020) [37] }\end{array}$ & $\begin{array}{l}\text { Double-center } \\
\text { experimental cohort } \\
\text { study }\end{array}$ & Live rats & Technical & $\begin{array}{l}\text { Expert instruction enhances } \\
\text { microsurgical performance vs } \\
\text { self-directed practice }\end{array}$ \\
\hline $\begin{array}{l}\text { Alshomer et al. } \\
\text { (2020) [38] }\end{array}$ & $\begin{array}{l}\text { Proposed technological } \\
\text { innovation (to be } \\
\text { validated) }\end{array}$ & Novel 3D printed tool & Technical & $\begin{array}{l}\text { Multiaxial/angular vessel orientation } \\
\text { for microvascular anastomosis } \\
\text { training simulating real clinical } \\
\text { cases }\end{array}$ \\
\hline $\begin{array}{l}\text { Oliveira et al. } \\
\text { (2018) [39] }\end{array}$ & $\begin{array}{l}\text { Experimental model for } \\
\text { neurosurgery }\end{array}$ & $\begin{array}{l}\text { Ex vivo human placenta } \\
\text { simulator }\end{array}$ & Technical & $\begin{array}{l}\text { Great resemblance with brain vessels, } \\
\text { practice bypass techniques }\end{array}$ \\
\hline $\begin{array}{l}\text { Malik et al. } \\
\text { (2017) [40] }\end{array}$ & $\mathrm{RCT}$ & $\begin{array}{l}\text { Home-based chicken femoral } \\
\text { artery }\end{array}$ & Technical & $\begin{array}{l}\text { Self-directed home-based training with } \\
\text { either jewelers microscope or iPad } \\
\text { has comparable results to } \\
\text { laboratory-based training using a } \\
\text { tabletop microscope }\end{array}$ \\
\hline $\begin{array}{l}\text { Yule et al. } \\
\text { (2018) [41] }\end{array}$ & $\begin{array}{l}\text { Double-center study of } \\
\text { construct validity }\end{array}$ & Simulated surgical videos & Non-technical & Validation of NOTSS tool \\
\hline
\end{tabular}

$L F$ low-fidelity, $H F$ high-fidelity, $V R$ virtual reality, $L o E$ level of evidence, SM supermicrosurgery, $R C T$ randomized controlled trial, NOTSS NonTechnical Skills for Surgeons

\section{Discussion}

\section{Alternative nonliving models as a stepping milestone for basic skill consolidation}

Microsurgery classrooms globally have recognized a principle shift toward the " 3 R's": (1) reducing the quantity of live animals used, (2) replacing live models with virtual or classroom learning, and (3) refining experimental designs [43]. The Animals (Scientific Procedures) Act 1986 Amendment Regulations 2012, paragraph 22/20B:(4) defines alternative strategies as "scientific methods and testing strategies which do not use protected animals, or which use fewer protected animals or reduce the pain, suffering, distress or lasting harm caused to protected animals" [44].
In order to abide by these regulations, researchers and policy creators have begun to recognize and started to turn to alternative educational modalities, such as nonliving models, virtual reality/augmented reality (VR/AR) and threedimensional tools for microvascular anastomosis training [45]. Thus, a reduction between 50 and $90 \%$ was achieved in the usage of living animal models because of enhanced skills gained through bench models prior to embarking on to the real live tissues of the rat model [46] without compromising the quality of training [47].

Other studies support that the re-use of animals or ex vivo human-based tissues, when appropriate, reduce the number of animals consumed in the microsurgical laboratories while improving basic skill sets [48]. For example, the human placenta 
model of education offers the opportunity to practice during multiple sessions, since there is a multitude of vessels to work with. These vessels are prepared with macrodissection or microdissection after removal of the outer membrane of the placenta [49-51]. A myriad of novel synthetic [52] (e.g., silicone [53, 54], polyvinyl alcohol gelatin tubes [55]) and biological training models has been devised [56-58], applicable to surgical specialties (e.g., hand [59, 60], urology [61, 62], otolaryngology [63], ophthalmology [64, 65], orthopedics [66]). Another example is the ex vivo ovine model for microsurgical training on parotidectomy and facial nerve reanimation [67]. Persistent, repeated, interval [68], deliberate, self-directed practice on low-fidelity platforms are excellent alternatives to high-fidelity models [69-71]. It is found that having previous practical experience with ex vivo models enhances skill retention [70, 72], confidence [73], and cognitive perception within the operating room because the technical skills have been mastered and become automatic. Using both living and nonliving models offers the opportunity to reach the highest level of competency needed in microvascular free tissue transfer; each modality offers a unique skill set to the trainee microsurgeon [70]. Transferable skills from nonliving models are acquired and applied successfully in the live rat model $[70,74,75]$. It should be emphasized that nonliving models work as an intermediate stage to consolidate basic skills prior to embarking on more advanced exercises in the living model. This allows for multitasking and increased efficiency within the operating room [76].

\section{Advantages of virtual reality and nonliving training models}

There is no doubt that nonliving models offer several advantages. Grober et al. [41] concluded that microsurgical skills attained in low- and high-fidelity training models are equally effective for novice participants. In the current COVID-19 era, where clinical exposure for trainees is minimized, VR/AR helps sustain skills through simulated-based practice [77-81]. Following the advent of new-age VR technology, the next goal was to determine its predictive validity in human operating rooms. Virtual reality was seen as a new educational tool to both appeal to a growing movement toward minimizing live animal use, and as a new technological wave to update curricula [82].

While early results are encouraging, multidimensional VR applications have remained somewhat limited to specific subprocedures of broader operations, such as harvesting of free fibula and transplanting it for femoral head osteonecrosis. As a result, select microsurgery courses have proposed modernized curricula consisting of a blend of both live and virtual learning experiences [83]. A wealth of digital content is now readily available and easily accessible to learn microsurgery via YouTube videos, phone applications, professional websites, and academic Institutions [84].
The porcine [46] and bovine [85] hearts and the microsurgical simulation model with pulsatile flow system [86] have been devised as alternative methods of education for the trainee microsurgeon. Another example is the home-based microsurgical training model; this modality was shown to be a realistic, cheap, and reproducible tool to help the trainee microsurgeon to maintain already obtained skills $[87,88]$. Another examples of a simple DIY type of simulator are the plant-based model which uses the halved stem of a chive for microsurgical anastomosis [89], the grapefruit training model for cerebral artery side-to-side microsurgical bypass procedure [90], and other innovations related to neurosurgery [91, 92]. Other considerable advantages of nonbiological microsurgical simulators include ease of setup and storage, low cost [93], low maintenance, repeated use, no risk of infectious disease transmission [82], and portability [94]. Thus, the transition from the ex vivo model to the in vivo one will be smooth for the resident [95-97].

\section{Disadvantages of nonliving models}

By working in isolation with artificial specimens, the trainee is unlikely to receive immediate feedback from an instructor, which would be deemed invaluable in building better microsurgical skills [36]. In contrast, residents are being monitored from real-time video projectors and assessed with hand motion analysis technology through sophisticated computer software [16, 98-101]. This offers an unparalleled experience of quality feedback from the instructors to the students [41]. Other microsurgical training programs incorporated electroencephalographic (EEG) monitoring to provide feedback to the trainees [102].

Nonliving models cannot replicate the physiological processes which take place within a living organism, such as thrombogenesis, natural blood flow, the real feel of the living tissues, and inflammatory processes secondary to traumatized tissues, while the trainee performs exercises and handles tissues in a rough manner. The basic structure of the vessel can be generated with technology. For instance, the adventitia and the vessel wall are possible to simulate with technology [103]; however, there is not yet a substitute for the intima and the role of the living endothelial cells [104].

Additionally, studies on andragogical and pedagogical theories support the view that trainees prefer to work with living models than nonliving tissues [95]. When it comes to training the future generation of microsurgeons, it is wise to ensure that the journey is enjoyable, and the educational techniques are standardized, well studied, and proven effective. The teaching modality should be attractive to the trainee microsurgeon in order to enhance the learning process.

Mitchell and Arora [105] stated that "knowledge, the standard of work, coping with complexity and perception of context" are the constructs of "the Dreyfus and Dreyfus model," 
which pertains to building surgical competencies. It is important to remember this andragogy model in microsurgical training because the goal is not only a vital anastomosis but also a well-rounded surgeon [105]. Decision-making constitutes most of the surgical skill, especially when it comes to raising flaps and performing more advanced microsurgical techniques. Emphasis should be placed on the right mindset, frustration, and stress management, along with interim practical sessions. A summary of pros and cons for both living and nonliving models is listed in Table 2 .

\section{Identifying the gap}

While microsurgery education tools have focused on the adoption of new technology and the latest cutting-edge supermicrosurgical simulation training curricula [106-108], we contend that the development of softer skills is necessary for a surgeon in an operating room. Microsurgery is a demanding core skill set with a steep learning curve applied across a variety of specialties. Often, students in a teaching lab are encouraged to perform many procedures as respective weeklong courses; procedures are tedious and often consume the entirety of a day. As such, the work is siloed, and surgeons are left to their own devices to adapt to a new environment and successfully produce viable vessels. However, a specialist surgeon should excel in the following nine categories: teamwork, communication, health advocacy, judgment, leadership, expertise, professionalism, scholarship, and technical expertise. All these skills should be addressed when devising a training curriculum in microsurgery [109].

Here, we notice a significant discrepancy between the educational setting and the real-world operating room; practicing surgeons in an operating room are often working together with multiple technicians, assistants, and even other surgeons. As such, many of the learned skill sets surgeons take from a microsurgery teaching lab need to be adjusted for the operating room working with others [110].
In recent years, non-technical skills have been more closely examined, both retroactively and proactively. The NonTechnical Skills for Surgeons (NOTSS) system has been adopted as a tool to provide feedback to surgeons in these important non-technical skills, comprised of 14 elements that are evaluated on a 4-point scale to provide transparency to surgeons on observed operating room behaviors [29]. Given the more widespread acknowledgment for the development of surgeons' non-technical skills, we propose microsurgery labs to likewise explore opportunities to adjust to contemporary andragogy models to develop a well-rounded microsurgeon.

\section{Bridging the gap: development of an integrated non- technical skill curriculum}

We suggest classrooms are already designed to easily incorporate NTS development. Microsurgery labs are often designed for 3-6 students in a weeklong course. This provides students with the opportunity to learn from each other, in addition to individual work. The culmination of a week of microsurgery procedures could manifest in a group procedure among students using either living or nonliving subjects. The microsurgery instructor can suggest a procedure which would require the group to work together to accomplish a goal. Instructors then evaluate students across a multitude of non-technical skill measurements in order to gauge readiness for the operating theater.

Similar to how the NOTSS system has proven an effective tool for non-technical skill evaluation [111], we outline a prospective grading system for implementation in existing microsurgery courses. Our scorecard mirrors elements of the NOTSS system, though layers of both process scoring and results scoring. The aim of the system is to provide both students and instructors with repeatable and predictable processes for successful microsurgical outcomes. We devised a similar grading system of 21 elements that has been tailored and weighted to fit the demands of a microsurgeon in a real operating environment. Each student is given a role (in a team) to execute an advanced microsurgery procedure, along with
Table 2 Summary of advantages and disadvantages of experimental living and nonliving microsurgical training models

\begin{tabular}{|c|c|c|}
\hline Type of models & Advantages & Disadvantages \\
\hline Living models & $\begin{array}{l}\text { Abundance of physiological tissues } \\
\text { Multiple exercises in } 1 \text { specimen } \\
\text { Hemostasis } \\
\text { Need for anesthesia and monitoring } \\
\text { Closer to human vessels } \\
\text { Improved simulation experience for learners } \\
\text { Development of NTS }\end{array}$ & $\begin{array}{l}\text { Ethical concerns } \\
\text { High cost (enrolment, maintenance) } \\
\text { Standard precautions } \\
\text { Steep learning curve } \\
\text { Expert instruction often required }\end{array}$ \\
\hline Nonliving models & $\begin{array}{l}\text { Significant reduction of live animals } \\
\text { Lower cost, easy setup (DIY synthetic kits) } \\
\text { VR simulation-enhanced visuospatial skills } \\
\text { Smooth transition to living models } \\
\quad \text { (transferable skills) }\end{array}$ & $\begin{array}{l}\text { Low fidelity } \\
\text { No circulation-inability to practice hemostasis } \\
\text { Infectious diseases (e.g., human placenta) } \\
\text { Inability to develop NTS }\end{array}$ \\
\hline
\end{tabular}

NTS non-technical skills, DIY do-it-yourself 
Table 3 Details of a hypothetical scenario in the context of a simulated microsurgical experimental environment with a focus on non-technical skill assessment and evaluation

\begin{tabular}{|c|c|c|c|}
\hline Category & Subcategories & Score & Feedback \\
\hline Situation awareness & $\begin{array}{l}\text { Gathering information, understanding situation, and anticipating the } \\
\text { future state } \\
\text { Respecting self-limitations } \\
\text { Recognizing stress/fatigue and taking actions to mitigate these } \\
\text { Taking breaks at appropriate intervals } \\
\text { WHO checklist, "timeout," safety first } \\
\text { Elimination distractions/interruptions within OR } \\
\text { Remaining vigilant }\end{array}$ & & \\
\hline $\begin{array}{l}\text { Communication and } \\
\text { teamwork }\end{array}$ & $\begin{array}{l}\text { Effective clear speech } \\
\text { Accurately exchanging clinical information within multidisciplinary } \\
\quad \text { team } \\
\text { Asking for help timely and appropriately } \\
\text { Liaising with anesthesiologist regarding intraoperative } \\
\quad \text { analgesia/sedation } \\
\text { Establishing a clear shared mental model on surgical plan } \\
\text { Psychomotor skills (i.e., coordination with assistant) }\end{array}$ & & \\
\hline Leadership & $\begin{array}{l}\text { Acting at a high standard of performance } \\
\text { Role modeling expert performance and behavior } \\
\text { Implementing strategies for stress relief (i.e., deep breathing, } \\
\quad \text { visualizing successful outcome) } \\
\text { Confident leadership style } \\
\text { Setting the pace }\end{array}$ & & \\
\hline Decision-making & $\begin{array}{l}\text { Considering different reconstructive options } \\
\text { Confirming which is the right next move with instructor, if unsure } \\
\text { Executing accurately the decision made }\end{array}$ & & \\
\hline
\end{tabular}

Scenario: You are the primary microsurgeon for the following case. You and your team are required to elevate a free groin flap and transfer it to the contralateral side with microvascular anastomosis. You are encouraged to use your assistant appropriately throughout the procedure. Another assistant is assigned the role of a "scrub nurse." The anesthesiologist is closely monitoring the "patient" (subject). You are given $3 \mathrm{~h}$ to perform this task guidelines for completion of the task (time, method, and roles). The surgeons are then asked to carry out the procedure under the parameters mentioned and to work together to accomplish the goal (Table 3). The validity of this novel assessment tool for NTS remains to be tested in a pilot cohort study.

\section{Conclusions}

The use of artificial models has generally proved to be more costeffective than the maintenance of an animal experimental laboratory. Every method of microsurgical training assists residents with the acquisition of a variety of skills. However, the combination of all pedagogical entities guarantees enhanced results. In a step-wise approach, it must be stressed that residents should always start practicing on simple low-fidelity models and then upgrade to more complex exercises with live models. However, training with live rats is considered the gold standard in the current microsurgical training. Our proposed scorecard attempts to evaluate non-technical skills. Due to the paucity of evidence in this field, future research should focus on developing curricula with integrated NTS specific to microsurgery.

\section{Declarations}

Ethical approval For this kind of article, formal consent from a local ethics committee is not required.

\section{Patient consent N/A}

Informed consent N/A

Conflict of interest Konstantinos Gasteratos, Joseph Robert Paladino, Yelena Akelina, and Horacio F. Mayer declare no conflict of interest.

\section{References}

1. Pafitanis G, Serrar Y, Raveendran M, Ghanem A, Myers S (2017) The chicken thigh adductor profundus free muscle flap: a novel validated non-living microsurgery simulation training model. Arch Plast Surg 44:293-300

2. Ramachandran S, Chui CH-K, Tan B-K (2013) The chicken aorta as a simulation-training model for microvascular surgery training. Arch Plast Surg 40:327-329

3. Chouari TAM, Lindsay K, Bradshaw E, Parson S, Watson L, Ahmed J, Curnier A (2018) An enhanced fresh cadaveric model for reconstructive microsurgery training. Eur J Plast Surg 41:439 446

4. Lannon DA, Atkins J-A, Butler PEM (2001) Non-vital, prosthetic, and virtual reality models of microsurgical training. Microsurgery: 389-393. https://doi.org/10.1002/micr.21709

5. Ghanem A, Kearns M, Ballestín A, Froschauer S, Akelina Y, Shurey S, Legagneux J, Ramachandran S, Cozzolino S, Ramakrishnan V, Pafitanis G, Zakaria Y, al-Maaytah K, Komatsu S, Kimata Y, Cifuentes I, Soucacos PN, Tos P, Myers S (2020) International microsurgery simulation society (IMSS) consensus statement on the minimum standards for a basic microsurgery course, requirements for a microsurgical anastomosis 
global rating scale and minimum thresholds for training. Injury. 51(Suppl 4):S126-S130

6. Tolba RH, Czigány Z, Osorio Lujan S, Oltean M, Axelsson M, Akelina Y, di Cataldo A, Miko I, Furka I, Dahmen U, Kobayashi E, Ionac M, Nemeth N (2017) Defining standards in experimental microsurgical training: recommendations of the European Society for Surgical Research (ESSR) and the International Society for Experimental Microsurgery (ISEM). Eur Surg Res 58:246-262

7. Kania K, Chang DK, Abu-Ghname A, Reece EM, Chu CK, Maricevich M, Buchanan EP, Winocour S (2020) Microsurgery training in plastic surgery. Plast Reconstr Surg Glob Open. 8:e2898

8. Dumestre D, Yeung JK, Temple-Oberle C (2014) Evidence-based microsurgical skill-acquisition series part 1: validated microsurgical models - a systematic review. J Surg Educ. 71:329-338

9. Almeland SK, Lindford A, Sundhagen HP, Hufthammer KO, Strandenes E, Svendsen HL, Guttormsen AB, Hansson E (2020) The effect of microsurgical training on novice medical students' basic surgical skills - a randomized controlled trial. Eur J Plast Surg 43:459-466

10. Evgeniou E, Walker H, Gujral S (2018) The role of simulation in microsurgical training. J Surg Educ. 75:171-181

11. Satterwhite T, Son J, Carey J, Echo A, Spurling T, Paro J, Gurtner G, Chang J, Lee GK (2014) The Stanford Microsurgery and Resident Training (SMaRT) Scale: validation of an on-line global rating scale for technical assessment. Ann Plast Surg 72(Suppl 1): S84-S88

12. Zhang D, Wu Z, Chen J, Gao A, Chen X, Li P, Wang Z, Yang G, Lo B, Yang GZ (2020) Automatic microsurgical skill assessment based on cross-domain transfer learning. IEEE Robot Autom Lett 5:4148-4155

13. Clarke NS, Price J, Boyd T, Salizzoni S, Zehr KJ, Nieponice A, Bajona P (2018) Robotic-assisted microvascular surgery: skill acquisition in a rat model. J Robot Surg 12:331-336

14. van Mulken TJM, Boymans CAEM, Schols RM, Cau R, Schoenmakers FBF, Hoekstra LT, Qiu SS, Selber JC, van der Hulst RRWJ (2018) Preclinical experience using a new robotic system created for microsurgery. Plast Reconstr Surg 142:13671376

15. Lee J-Y, Mattar T, Parisi TJ, Carlsen BT, Bishop AT, Shin AY (2012) Learning curve of robotic-assisted microvascular anastomosis in the rat. J Reconstr Microsurg 28:451-456

16. Nugent E, Joyce C, Perez-Abadia G, Frank J, Sauerbier M, Neary P, Gallagher AG, Traynor O, Carroll S (2012) Factors influencing microsurgical skill acquisition during a dedicated training course. Microsurgery. 32:649-656

17. Ribeiro de Oliveira MM, Ramos TM, Ferrarez CE, Machado CJ, Vieira Costa PH, Alvarenga DL et al (2019) Development and validation of the Skills Assessment in Microsurgery for Brain Aneurysms (SAMBA) instrument for predicting proficiency in aneurysm surgery. J Neurosurg 14:1-7

18. Qassemyar Q, Boulart L (2015) A 4-task skills examination for residents for the assessment of technical ability in hand trauma surgery. J Surg Educ. 72:179-183

19. Zheng YD, Nicolas CF, Corvi JJ, Kurtzman JS, Park KH, Coley SM, Marboe CC, Akelina Y, Strauch RJ (2020) Large and uneven bites in end-to-end anastomosis of the rat femoral artery. $\mathrm{J}$ Reconstr Microsurg 36:486-493

20. Kim E, Norman ICF, Myers S, Singh M, Ghanem A (2020) The end game - a quantitative assessment tool for anastomosis in simulated microsurgery. J Plast Reconstr Aesthet Surg 73:1116-1121

21. Schaverien MV, Liu J, Butler CE, Selber JC (2018) Factors correlating with microsurgical performance: a clinical and experimental study. J Surg Educ. 75:1045-1051

22. Chan W, Niranjan N, Ramakrishnan V (2010) Structured assessment of microsurgery skills in the clinical setting. J Plast Reconstr Aesthet Surg 63:1329-1334
23. Balasundaram I, Aggarwal R, Darzi LA (2010) Development of a training curriculum for microsurgery. Br J Oral Maxillofac Surg 48:598-606

24. Atkins JL, Kalu PU, Lannon DA, Green CJ, Butler PEM (2005) Training in microsurgical skills: assessing microsurgery training. Microsurgery:481-485. https://doi.org/10.1002/micr.20150

25. Dumestre D, Yeung JK, Temple-Oberle C (2015) Evidence-based microsurgical skills acquisition series part 2: validated assessment instruments-a systematic review. J Surg Educ 72:80-89

26. Campos MEC, de Oliveira MMR, Reis AB, de Assis LB, Iremashvili V (2020) Development and validation a taskspecific checklist for a microsurgical varicocelectomy simulation model. Int Braz J Urol 46:796-802

27. Flin R, O'Connor P (2017) Safety at the sharp end: a guide to nontechnical skills. CRC Press, Taylor \& Francis Group, Boca Raton, USA

28. Flin R, Yule S, Paterson-Brown S, Maran N, Rowley D, Youngson $G$ (2007) Teaching surgeons about non-technical skills. Surgeon. 5:86-89

29. Yule S, Flin R, Paterson-Brown S, Maran N, Rowley D (2006) Development of a rating system for surgeons' non-technical skills. Med Educ 40:1098-1104

30. Tamai S (2003) The history of microsurgery. Experimental and clinical reconstructive microsurgery. 3-24. In: Tamai S., Usui M., Yoshizu T. (eds) Experimental and Clinical Reconstructive Microsurgery. Springer, Tokyo. https://doi.org/10.1007/978-4431-67865-6 1

31. Javid P, Aydın A, Mohanna P-N, Dasgupta P, Ahmed K (2019) Current status of simulation and training models in microsurgery: a systematic review. Microsurgery. 39:655-668

32. Bergmeister KD, Aman M, Kramer A, Schenck TL, Riedl O, Daeschler SC, Aszmann OC, Bergmeister H, Golriz M, Mehrabi A, Hundeshagen G, Enkhbaatar P, Kinsky MP, Podesser BK (2020) Simulating surgical skills in animals: systematic review, costs \& acceptance analyses. Front Vet Sci 7:570852

33. Rigalli A, Di Loreto V (2016) Experimental surgical models in the laboratory rat. CRC Press, Taylor \& Francis Group, Boca Raton, USA. https://doi.org/10.1201/9781420093278

34. Lefevre E, Rogers A (2020) Carotid artery vein-pouch bifurcation aneurysm in rats: an experimental model for microneurosurgical training. Neurochirurgie. 66:183-188

35. Safi A-F, Safi S, Tayeh M, Gojowy D, Timmer M, Goldbrunner R, Kauke M (2019) Vein Graft Interposition: a training model using gradually thawed cryopreserved vessels. J Craniofac Surg 30:e213-e216

36. Paladino J, Gasteratos K, Akelina Y, Marshall B, Papazoglou LG, Strauch RJ (2020) The benefits of expert instruction in microsurgery courses. J Reconstr Microsurg 37:143-153

37. Shurey S, Akelina Y, Legagneux J, Malzone G, Jiga L, Ghanem AM (2014) The rat model in microsurgery education: classical exercises and new horizons. Arch Plast Surg 41:201-208

38. Carr S, McDermott BR, McInerney N, Hussey A, Byrne D, Potter S (2019) Determining the effect of external stressors and cognitive distraction on microsurgical skills and performance. Front Surg 6: 77

39. Pavlidis I, Zavlin D, Khatri AR, Wesley A, Panagopoulos G, Echo A (2019) Absence of stressful conditions accelerates dexterous skill acquisition in surgery. Sci Rep 9:1747

40. Hanrahan J, Sideris M, Pasha T, Tsitsopoulos PP, Theodoulou I, Nicolaides M, Georgopoulou EM, Kombogiorgas D, Bimpis A, Papalois A (2018) Hands train the brain-what is the role of hand tremor and anxiety in undergraduate microsurgical skills? Acta Neurochir 160:1673-1679

41. Grober ED, Hamstra SJ, Wanzel KR, Reznick RK, Matsumoto ED, Sidhu RS, Jarvi KA (2004) The educational impact of bench 
model fidelity on the acquisition of technical skill: the use of clinically relevant outcome measures. Ann Surg 240:374-381

42. Gauthier C, Griffin G (2005) Using animals in research, testing and teaching. Rev Sci Tech 24:735-745

43. Akelina Y (2003) Applying the " 3 Rs": training course in surgical techniques. Lab Anim 32:41-44

44. Hollands C (1986). The Animals (Scientific Procedures) Act 1986. Lancet 5;2(8497):32-3

45. Alshomer F, Alhazmi B, Alowais F, Aldekhayel S (2020) A lowcost 3D-printed tool with multiaxial/angular vessel orientation for microvascular anastomosis training. Plast Reconstr Surg Glob Open 8:e2567

46. Schöffl H, Froschauer SM, Dunst KM, Hager D, Kwasny O, Huemer GM (2008) Strategies for the reduction of live animal use in microsurgical training and education. Altern Lab Anim $36: 153-160$

47. Lahiri A, Muttath SS, Yusoff SK, Chong AK (2020) Maintaining effective microsurgery training with reduced utilisation of live rats. J Hand Surg Asian Pac Vol 25:206-213

48. de Boo J, Hendriksen C (2005) Reduction strategies in animal research: a review of scientific approaches at the intra-experimental, supra-experimental and extra-experimental levels. Altern Lab Anim 33:369-377

49. Romero FR, Fernandes ST, Chaddad-Neto F, Ramos JG, de Campos JM, de Oliveira E (2008) Microsurgical techniques using human placenta. Arq Neuropsiquiatr 66:876-878

50. Oliveira MM, Wendling L, Malheiros JA, Nicolato A, Prosdocimi A, Guerra L, Costa PHV, Ferrarez CE, Ferreira MT, Sauvageau E, Hanel R (2018) Human placenta simulator for intracranialintracranial bypass: vascular anatomy and 5 bypass techniques. World Neurosurg. 119:e694-e702

51. Belykh E, Miller EJ, Lei T, Chapple K, Byvaltsev VA, Spetzler RF et al (2017) Face, content, and construct validity of an aneurysm clipping model using human placenta. World Neurosurg 105:952-960.e2

52. Willis RE, Wiersch J, Adams AJ, Al Fayyadh MJ, Weber RA, Wang HT (2017) Development and evaluation of a simulation model for microvascular anastomosis training. J Reconstr Microsurg 33:493-501

53. Gul BU, Yanilmaz DK, Arslan D, Bayramicli M, Akbulut O (2019) Silicone-based simulation models for peripheral nerve microsurgery. J Plast Reconstr Aesthet Surg 72:477-483

54. Luther G, Blazar P, Dyer G (2019) Achieving microsurgical competency in orthopaedic residents utilizing a self-directed microvascular training curriculum. J Bone Joint Surg Am 101:e10

55. Atlan M, Lellouch AG, Legagneux J, Chaouat M, Masquelet A-C, Letourneur D (2018) A new synthetic model for microvascular anastomosis training? A randomized comparative study between silicone and polyvinyl alcohol gelatin tubes. J Surg Educ. 75:182-187

56. Altun A, Çokluk C (2019) The microneurosurgical training model for intrinsic and extrinsic brain tumor surgery using polyurethane foam and fresh cadaveric cow brain: an experimental study. World Neurosurg X 4:100039

57. Bedi MS, Bhavthankar TD, Girijala MR, Babu JK, Ambati V, Jonalgadda V, Ogando-Rivas E, Konchada K, Juluru CS, Jvnk A (2019) Lazy glass microsurgical trainer: a frugal solution for microsurgical training. World Neurosurg. 125:433-442

58. Pafitanis G, Veljanoski D, Ghanem AM, Myers S (2018) Pork belly: a simulation training model for intramuscular perforator dissection. Plast Reconstr Surg Glob Open 6:e1674

59. Ortiz R, Sood RF, Wilkens S, Gottlieb R, Chen NC, Eberlin KR (2019) Longitudinal microsurgery laboratory training during hand surgery fellowship. J Reconstr Microsurg 35:640-645

60. Christensen TJ, Anding W, Shin AY, Bishop AT, Moran SL (2015) The influence of microsurgical training on the practice of hand surgeons. J Reconstr Microsurg 31:442-449
61. Pinto LOAD, de Barros CAV, de Lima AB, Dos Santos DR, de Bacelar HPH (2019) Portable model for vasectomy reversal training. Int Braz J Urol 45:1013-1019

62. Mehta A, Li PS, Goldstein M (2014) Male infertility microsurgical training. Transl Androl Urol 3:134-141

63. Zambricki EA, Bergeron JL, DiRenzo EE, Sung CK (2016) Phonomicrosurgery simulation: a low-cost teaching model using easily accessible materials. Laryngoscope. 126:2528-2533

64. Koukkoulli A, Chandra A, Sheth H, Okhravi N, Verma S, Sullivan P, Ezra DG (2015) Bridging the gap: theory-based design of a microsurgical skills course for ophthalmology residents. J Surg Educ 72:585-591

65. Altunrende ME, Hamamcioglu MK, Hicdonmez T, Akcakaya MO, Brrgilı B, Cobanoglu S (2014) Microsurgical training model for residents to approach to the orbit and the optic nerve in fresh cadaveric sheep cranium. J Neurosci Rural Pract 5:151-154

66. Ko J-WK, Lorzano A, Mirarchi AJ (2015) Effectiveness of a microvascular surgery training curriculum for orthopaedic surgery residents. J Bone Joint Surg Am 97:950-955

67. Ghirelli M, Federici G, Melchiorri C, Malagoli A, Presutti L, Fernandez IJ (2020) Ex vivo ovine model for surgical and microsurgical training on parotidectomy and facial nerve reanimation: proposal of structured training program. J Reconstr Microsurg. https://doi.org/10.1055/s-0040-1721122

68. Schoeff S, Hernandez B, Robinson DJ, Jameson MJ, Shonka DC $\mathrm{Jr}$ (2017) Microvascular anastomosis simulation using a chicken thigh model: interval versus massed training. Laryngoscope. 127: 2490-2494

69. Brown JS, Rapaport BHJ (2019) Role of live animals in the training of microvascular surgery: a systematic review. Br J Oral Maxillofac Surg 57:616-619

70. Ghanem AM, Hachach-Haram N, Leung CCM, Myers SR (2013) A systematic review of evidence for education and training interventions in microsurgery. Arch Plast Surg:312. https://doi.org/10. 5999/aps.2013.40.4.312

71. Brosious JP, Kleban SR, Goldman JJ, Mohsin AG, Williams SJ, Wang WZ, Menezes J, Baynosa R (2019) Ahead of the curve: tracking progress in novice microsurgeons. J Reconstr Microsurg 35:216-220

72. Pafitanis G, Cooper L, Hadjiandreou M, Ghanem A, Myers S (2019) Microvascular anastomotic coupler application learning curve: a curriculum supporting further deliberate practice in exvivo simulation models. J Plast Reconstr Aesthet Surg 72:203210

73. Shulzhenko NO, Zeng W, Albano NJ, Lyon SM, Wieland AM, Mahajan AY, Williams D, Bentz ML, Poore SO (2020) Multispecialty microsurgical course utilizing the blue-blood chicken thigh model significantly improves resident comfort, confidence, and attitudes in multiple domains. J Reconstr Microsurg $36: 142-150$

74. Rodriguez JR, Yañez R, Cifuentes I, Varas J, Dagnino B (2016) Microsurgery workout: a novel simulation training curriculum based on nonliving models. Plast Reconstr Surg 138:739e-747e

75. Mokhtari P, Tayebi Meybodi A, Lawton MT, Payman A, Benet A (2017) Transfer of learning from practicing microvascular anastomosis on silastic tubes to rat abdominal aorta. World Neurosurg 108:230-235

76. Palter VN, Grantcharov T, Harvey A, Macrae HM (2011) Ex vivo technical skills training transfers to the operating room and enhances cognitive learning: a randomized controlled trial. Ann Surg 253:886-889

77. Ramella V, Papa G, Bottosso S, Cazzato V, Arnež ZM (2020) Microsurgical reconstruction in the time of COVID-19. Microsurgery. 40:723 
78. Mayer HF, Persichetti P (2020) Plastic surgery during the COVID-19 pandemic times. Eur J Plast Surg 43:361-362. https://doi.org/10.1007/s00238-020-01685-1

79. Hughes BA, Stallard J, West CC (2020) The use of Whatsapp® as a way to deliver plastic surgery teaching during the COVID-19 pandemic. J Plast Reconstr Aesthet Surg 73:e1-e2

80. Ropelato S, Menozzi M, Michel D, Siegrist M (2020) Augmented reality microsurgery: a tool for training micromanipulations in ophthalmic surgery using augmented reality. Simul Healthc 15: $122-127$

81. Choque-Velasquez J, Colasanti R, Collan J, Kinnunen R, Rezai Jahromi B, Hernesniemi J (2018) Virtual reality glasses and "eyehands blind technique" for microsurgical rraining in neurosurgery. World Neurosurg. 112:126-130

82. Abi-Rafeh J, Zammit D, Jaberi MM, Al-Halabi B, Thibaudeau S (2019) Nonbiological microsurgery simulators in plastic surgery training. Plast Reconstr Surg:496e-507e. https://doi.org/10.1097/ prs.0000000000005990

83. Beris A, Kostas-Agnantis I, Gkiatas I, Gatsios D, Fotiadis D, Korompilias A (2020) Microsurgery training: a combined educational program. Injury. 51:S131-S134

84. Margulies IG, Xu H, Henderson PW (2020) Microsurgery training in the digital era: a systematic review of accessible digital resources. Ann Plast Surg 85:337-343

85. Olijnyk LD, Patel K, Brandão MR, de Morais ANL, de Carvalho RF, Severino AG, Mayor D, da Silva CE, Stefani MA (2019) The role of low-cost microsurgical training models and experience with exercises based on a bovine heart. World Neurosurg. 130: 59-64

86. Gallardo FC, Bustamante JL, Martin C, Orellana CM, Rojas Caviglia M, Garcia Oriola G, Diaz AI, Rubino PA, Quilis Quesada V (2020) Novel simulation model with pulsatile flow system for microvascular training, research, and improving patient surgical outcomes. World Neurosurg. 143:11-16

87. Loh CYY, Tiong VTY, Loh AYH, Athanassopoulos T (2014) Microsurgery training-a home do-it-yourself model. Microsurgery:417-418. https://doi.org/10.1002/micr.22242

88. Malik MM, Hachach-Haram N, Tahir M, Al-Musabi M, Masud D, Mohanna P-N (2017) Acquisition of basic microsurgery skills using home-based simulation training: a randomised control study. J Plast Reconstr Aesthet Surg 70:478-486

89. Reekie TA, Barnard AR, Hodginkson PD (2013) A novel plantbased model for developing microsurgical anastomotic skills. J Plast Reconstr Aesthet Surg 66:574-575 author reply 575-7

90. Cikla U, Rowley P, Jennings Simoes EL, Ozaydin B, Goodman SL, Avci E, Baskaya MK, Patel NJ (2020) Grapefruit training model for distal anterior cerebral artery side-to-side bypass. World Neurosurg. 138:39-51

91. Giovani A, Sandu AM, Petrescu G, Gorgan RM, Goel A (2019) Application of microanastomosis techniques in vascular neurosurgery training and innovation of future surgical strategies for giant aneurysms. World Neurosurg. 122:e1120-e1127

92. Yadav YR, Parihar V, Ratre S, Kher Y, Iqbal M (2016) Microneurosurgical skills training. J Neurol Surg A Cent Eur Neurosurg 77:146-154

93. Chung S-B, Ryu J, Chung Y, Lee SH, Choi SK (2017) An affordable microsurgical training system for a beginning neurosurgeon: how to realize the self-training laboratory. World Neurosurg. 105: 369-374

94. Ryu J, Choi SK, Chung Y, Lee SH, Jeong B-O (2017) A portable training model for deep bypass surgery. World Neurosurg 107: 263-267

95. Rigalli A, Di Loreto VE (2009) Experimental models for the study of diabetes. Experimental Surgical Models in the Laboratory Rat. 109-113. CRC Press, Taylor \& Francis Group, Boca Raton, USA. https://doi.org/10.1201/9781420093278.sec5
96. Remie R (2001) The PVC-rat and other alternatives in microsurgical training. Lab Anim 30:48-52

97. Chacon MA, Myers PL, Patel AU, Mitchell DC, Langstein HN, Leckenby JI (2020) Pretest and posttest evaluation of a longitudinal, residency-integrated microsurgery course. Ann Plast Surg 85: S122-S126

98. Miller R, Pafitanis G (2018) Loop ligation: objective assessment of surgical efficiency in vessel ligation with electromagnetic hand motion analysis. J Surg Sim:60-63. https://doi.org/10.1102/20517726.2018.0009

99. Applebaum MA, Doren EL, Ghanem AM, Myers SR, Harrington M, Smith DJ (2018) Microsurgery competency during plastic surgery residency: an objective skills assessment of an integrated residency training program. Eplasty 18:e25

100. Hamada MW, Pafitanis G, Nistor A, Kim YH, Myers S, Ghanem A (2020) Validation of an in vivo porcine simulation model of pedicled latissimus dorsi myocutaneous flap elevation. Eur J Plast Surg. https://doi.org/10.1007/s00238-020-01734-9

101. McGoldrick RB, Davis CR, Paro J, Hui K, Nguyen D, Lee GK (2015) Motion analysis for microsurgical training: objective measures of dexterity, economy of movement, and ability. Plast Reconstr Surg 136:231e-240e

102. Ros T, Moseley MJ, Bloom PA, Benjamin L, Parkinson LA, Gruzelier JH (2009) Optimizing microsurgical skills with EEG neurofeedback. BMC Neurosci 10:87

103. Alser O, Youssef G, Myers S, Ghanem AM (2020) A novel threein-one silicone model for basic microsurgery training. Eur J Plast Surg 43:621-626

104. Ilie VG, Ilie VI, Dobreanu C, Ghetu N, Luchian S, Pieptu D (2008) Training of microsurgical skills on nonliving models. Microsurgery. 28:571-577

105. Mitchell EL, Arora S (2012) How educational theory can inform the training and practice of vascular surgeons. J Vasc Surg 56: 530-537

106. Pafitanis G, Narushima M, Yamamoto T, Raveendran M, Veljanoski D, Ghanem AM, Myers S, Koshima I (2018) Evolution of an evidence-based supermicrosurgery simulation training curriculum: a systematic review. J Plast Reconstr Aesthet Surg 71:976-988

107. Bas CE, Cwykiel J, Siemionow M (2017) A new supermicrosurgery training model of saphenous artery and great saphenous vein anastomosis for development of advanced microsurgical skills. J Reconstr Microsurg 33:426-434

108. Cifuentes IJ, Rodriguez JR, Yañez RA, Salisbury MC, Cuadra ÁJ, Varas JE, Dagnino B (2016) A novel ex vivo training model for acquiring supermicrosurgical skills using a chicken leg. J Reconstr Microsurg 32:699-705

109. Martin J, Blennerhassett J, Hardman D, Mundy J (2009) Development of the surgical science examination of the Royal Australasian College of Surgeons surgical education and training programme: putting the chicken before the egg. ANZ J Surg:169 174. https://doi.org/10.1111/j.1445-2197.2008.04835.x

110. Yule S, Gupta A, Gazarian D, Geraghty A, Smink DS, Beard J et al (2018) Construct and criterion validity testing of the NonTechnical Skills for Surgeons (NOTSS) behaviour assessment tool using videos of simulated operations. Br J Surg:719-727. https:// doi.org/10.1002/bjs.10779

111. Whittaker G, Abboudi H, Khan MS, Dasgupta P, Ahmed K (2015) Teamwork assessment tools in modern surgical practice: a systematic review. Surg Res Pract 2015:494827

Publisher's note Springer Nature remains neutral with regard to jurisdictional claims in published maps and institutional affiliations. 